Received: 14 June 2017

Accepted: 1 December 2017

Published online: 19 December 2017

\section{Industrial-age doubling of snow accumulation in the Alaska Range linked to tropical ocean warming}

\author{
Dominic Winski ${ }^{1}$, Erich Osterberg ${ }^{1}{ }^{1}$, David Ferris ${ }^{1}$, Karl Kreutz ${ }^{2}$, Cameron Wake $^{3}$, Seth \\ Campbell ${ }^{2}$, Robert Hawley ${ }^{1}$, Samuel Roy ${ }^{2}$, Sean Birkel ${ }^{2}$, Douglas Introne ${ }^{2}$ \& Michael Handley ${ }^{2}$
}

Future precipitation changes in a warming climate depend regionally upon the response of natural climate modes to anthropogenic forcing. North Pacific hydroclimate is dominated by the Aleutian Low, a semi-permanent wintertime feature characterized by frequent low-pressure conditions that is influenced by tropical Pacific Ocean temperatures through the Pacific-North American (PNA) teleconnection pattern. Instrumental records show a recent increase in coastal Alaskan precipitation and Aleutian Low intensification, but are of insufficient length to accurately assess low frequency trends and forcing mechanisms. Here we present a 1200-year seasonally-to annually-resolved ice core record of snow accumulation from Mt. Hunter in the Alaska Range developed using annual layer counting and four ice-flow thinning models. Under a wide range of glacier flow conditions and layer counting uncertainty, our record shows a doubling of precipitation since $\sim 1840 \mathrm{CE}$, with recent values exceeding the variability observed over the past millennium. The precipitation increase is nearly synchronous with the warming of western tropical Pacific and Indian Ocean sea surface temperatures. While regional $20^{\text {th }}$ Century warming may account for a portion of the observed precipitation increase on Mt. Hunter, the magnitude and seasonality of the precipitation change indicate a long-term strengthening of the Aleutian Low.

The regional precipitation response to anthropogenic forcing is an area of intense research because of potential societal impacts through changes in mean hydroclimate state and the frequency and magnitude of floods and drought ${ }^{1,2}$. General circulation models (GCMs) project an overall 1.5-2\% increase in global precipitation per degree of warming and an increased contrast between wet and dry areas ${ }^{3}$. However, the hypothesized precipitation increase and regional wet-dry patterns are equivocal in the relatively short instrumental record, particularly over land ${ }^{4}$.

One region that has experienced significant $20^{\text {th }}$ century precipitation change is the North Pacific, where wintertime precipitation is largely governed by the strength of the Aleutian Low. A stronger Aleutian Low is associated with enhanced northward flow of relatively warm, moist air masses into Alaska, causing increased wintertime precipitation along the southern Alaska coast ${ }^{5}$. From 1950 to 2011, many coastal Alaskan weather stations experienced significant increases in winter precipitation (Juneau: $+40 \%$; Kodiak: $+67 \%$; Palmer: $+36 \%$; Seward: $+35 \%$; Yakutat: $+26 \%)^{6}$ in concert with a strengthening Aleutian Low. However, the Aleutian Low has strong interannual to multidecadal variability ${ }^{5}$ including a state shift in $1976^{7,8}$, so the short observational period (60-65 years) limits our ability to assess secular trends in regional precipitation ${ }^{9}$. A critical but unresolved question is whether the recent changes in the Aleutian Low and North Pacific precipitation are within the range of natural interannual to decadal-scale climate variability.

Here, we present a seasonally- to annually-resolved 1200-year ice core record of North Pacific precipitation to provide long-term context for the observed trend since the 1950s, and to evaluate forcing mechanisms. Our record is derived from two ice cores (each $208 \mathrm{~m}$ long) collected from the Mt. Hunter summit plateau $\left(62^{\circ} 56^{\prime} \mathrm{N}, 151^{\circ} 5^{\prime} \mathrm{W}\right.$, $3900 \mathrm{~m}$ ) in Denali National Park, Alaska. A high snow accumulation rate ( $1.15 \mathrm{~m}$ water equivalent [w. e.] average since 1900) and infrequent surface melt ( $<0.5 \%$ of the core is composed of refrozen melt layers and lenses) at the Mt. Hunter drill site preserve robust seasonal oscillations of several chemical parameters $\left(\mathrm{Na}, \mathrm{Ca}, \mathrm{Mg}, \mathrm{NH}_{4}{ }^{+}\right.$, MSA, $\delta^{18} \mathrm{O}$, liquid conductivity, dust concentration), facilitating annual layer counting back to $800 \mathrm{CE}$ (Fig. 1).

${ }^{1}$ Department of Earth Sciences, Dartmouth College, Hanover, NH, 03755, USA. ${ }^{2}$ Climate Change Institute and School of Earth and Climate Sciences, University of Maine, Orono, Maine, 04469, USA. ${ }^{3}$ Institute for the Study of Earth, Oceans, and Space, University of New Hampshire, Durham, NH, 03824, USA. Correspondence and requests for materials should be addressed to D.W. (email: dominic.a.winski.gr@dartmouth.edu) 


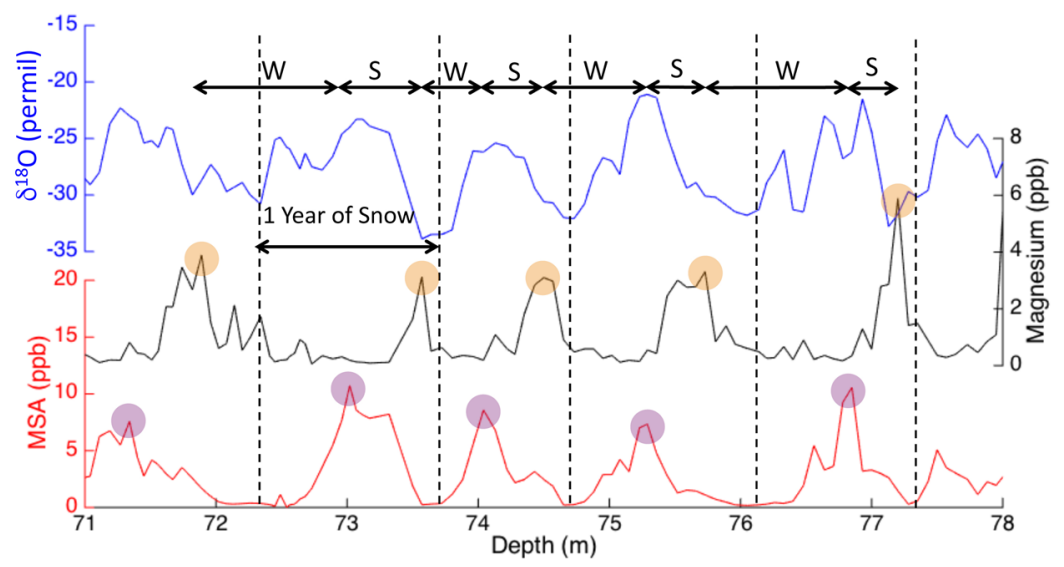

Figure 1. Annual layer counting in the Mt. Hunter ice core. (A) Three chemical series exhibiting annual layers are shown at a representative depth of core: $\mathrm{Mg}$ (black), $\delta^{18} \mathrm{O}$ (blue) and MSA (red). Each vertical dotted line represents the depth of Jan. $1^{\text {st }}$ in a $\delta^{18} \mathrm{O}$ trough and just below a Mg peak. The distance between each vertical dotted line represents one year's snow accumulation (before thinning correction). The position of these years was selected three times by three independent researchers. We delineate summer (May-August) and winter (September-April) seasons by recording the late summer-fall peak positions of MSA (purple circles) and the spring peak positions of $\mathrm{Mg}$ (orange circles).

All ice core accumulation rate records are subject to progressive annual layer thinning at depth due to glacier flow ${ }^{10}$, which must be corrected to determine the true accumulation-rate time series. We correct for layer thinning using four ice-flow models to obtain a conservative estimate of uncertainty in the Denali accumulation record ${ }^{11-13}$. One of the models is a 3-dimensional finite element model from Campbell et al. ${ }^{14}$ (hereafter the "Campbell model"), which is derived from the well-characterized basin geometry and surface ice velocities (determined by extensive geophysical surveys) at the Mt. Hunter drill site ${ }^{14}$. The other models are based on approaches from sites where previously published ice core accumulation rates have been reconstructed. We vary the model inputs such that each of the four models includes multiple simulations representing the entire range of plausible geophysical conditions at the drill site. Specific details on the mechanics of each thinning model, the exploration of a range of plausible thinning scenarios and the quantification of model uncertainty can be found in the Supplemental Information. While previous alpine ice core accumulation records ${ }^{15-21}$ are based on only one flow model for thinning corrections, the use of four different flow thinning models, the extensive characterization of drill site geometry and geophysical attributes ${ }^{14}$, careful quantification of timescale uncertainty, and the use of two ice cores from the same drill site, combine to significantly increase our confidence in the veracity of the Denali accumulation record. Critically, the four different flow models all produce similar trends in accumulation since $1500 \mathrm{CE}$.

\section{Results}

The annually resolved Denali snow accumulation record (Fig. 2) indicates that the post-1950 precipitation increase in the Alaskan weather station records began well before the $20^{\text {th }}$ century, in circa 1840 CE. The Campbell model produces the smallest accumulation increase since 1840 (Fig. 3), with a doubling of the median accumulation rate between $1600-1840\left(0.58 \mathrm{~m} \mathrm{a}^{-1}\right)$ and $1950-2013\left(1.29 \mathrm{~m} \mathrm{a}^{-1}\right)$, and an average increase of $9.6 \mathrm{~mm} \mathrm{a}^{-2}$ over the later period (Figs 2,3). The first 700 years $(800-1500 \mathrm{CE})$ of the record are characterized by multi-decadal variability and larger uncertainties among our thinning model ensemble that allow for a declining or rising long-term accumulation trend from 800-1500 CE (Fig. 3). Despite the larger uncertainties before $1500 \mathrm{CE}$, the Denali record shows that accumulation rates from 1950-2013 were the highest of the last 1200 years under all plausible conditions of glacier flow or layer counting uncertainty (Figs 2 and 3). There is nearly complete agreement between the accumulation records in the two Denali ice cores, with a correlation coefficient of 0.92 $(\mathrm{p}<0.001)$. Here, and throughout the text, $\mathrm{p}$-values are adjusted to account for the reduced effective sample size resulting from autocorrelation.

From 1867-2013 CE (133 m depth), the Denali accumulation record can be confidently separated into summer (May-August) and winter (September-April) accumulation due to the high sampling resolution and thick annual layers (Fig. 2 inset). This summer-winter parsing is performed using spring peaks in magnesium (from dust) and late summer-fall peaks in methanesulfonic acid (MSA), which have consistent offsets from other seasonal indicators including ammonium (summer) and $\delta^{18} \mathrm{O}$ (summer peak, winter trough; see Methods; Fig. 1). Figure 2 inset shows that the recent doubling of annual accumulation is dominated by a wintertime increase of $3.6 \mathrm{~mm} \mathrm{a}^{-2}$ since 1867 , representing an increase of $117 \%$ over this interval. The increase in Denali winter accumulation is highly significant $(\mathrm{p}<0.001)$ in both Denali ice cores based on comparison of the winter means from 1870-1900 and 1980-2010, and a non-parametric Thiel-Sen robust linear regression ${ }^{22}$.

Winter Denali accumulation is highly and significantly correlated with winter precipitation at several southern coastal Alaska weather stations, including Valdez, Yakutat, Seward, Juneau, Homer, and Kodiak (Table 1, Fig. 4). The significant correlations $(\mathrm{p}<0.05)$ with Alaskan station data provide additional confidence in our 


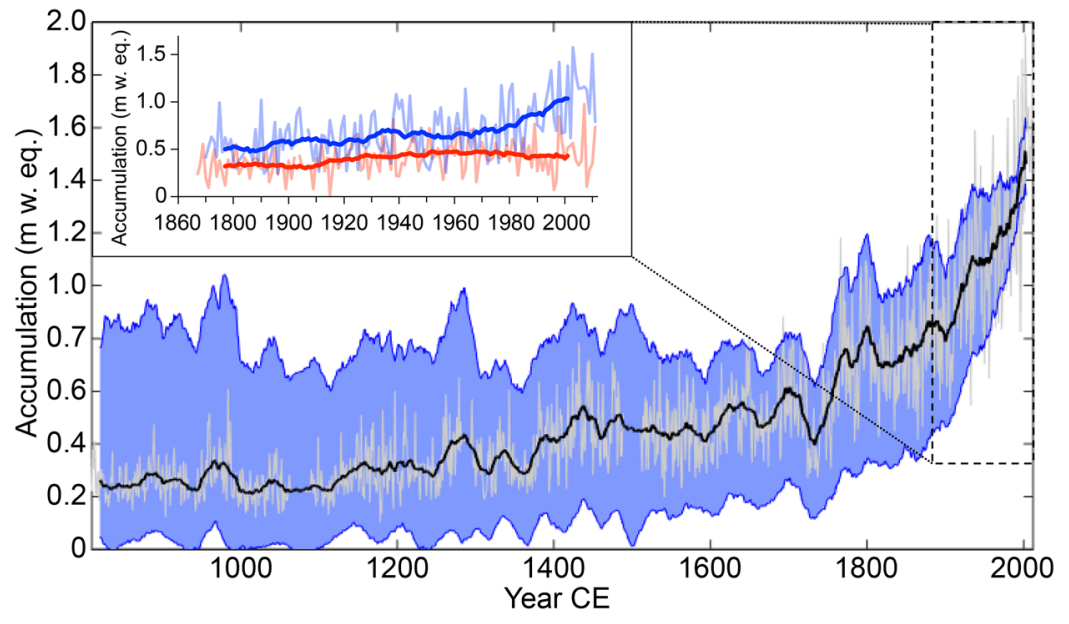

Figure 2. The Mt. Hunter accumulation record. Annual (light gray line) and 21-year smoothed (black line) accumulation time series from the year $810 \mathrm{CE}$ to present, constrained by 21-year smoothed error envelopes (blue shading) inclusive of stochastic, peak position and layer-thinning model uncertainties (see Methods section), including the total uncertainty range among all four modeling approaches. The inset shows seasonal trends in accumulation since 1867 with 21-year running means (bold lines). Snowfall accumulating between September and April (blue) has more than doubled, with a faster rise since 1976. Summer accumulation (April to August; red) remained comparatively stable except for a baseline shift between 1909 and 1925 .

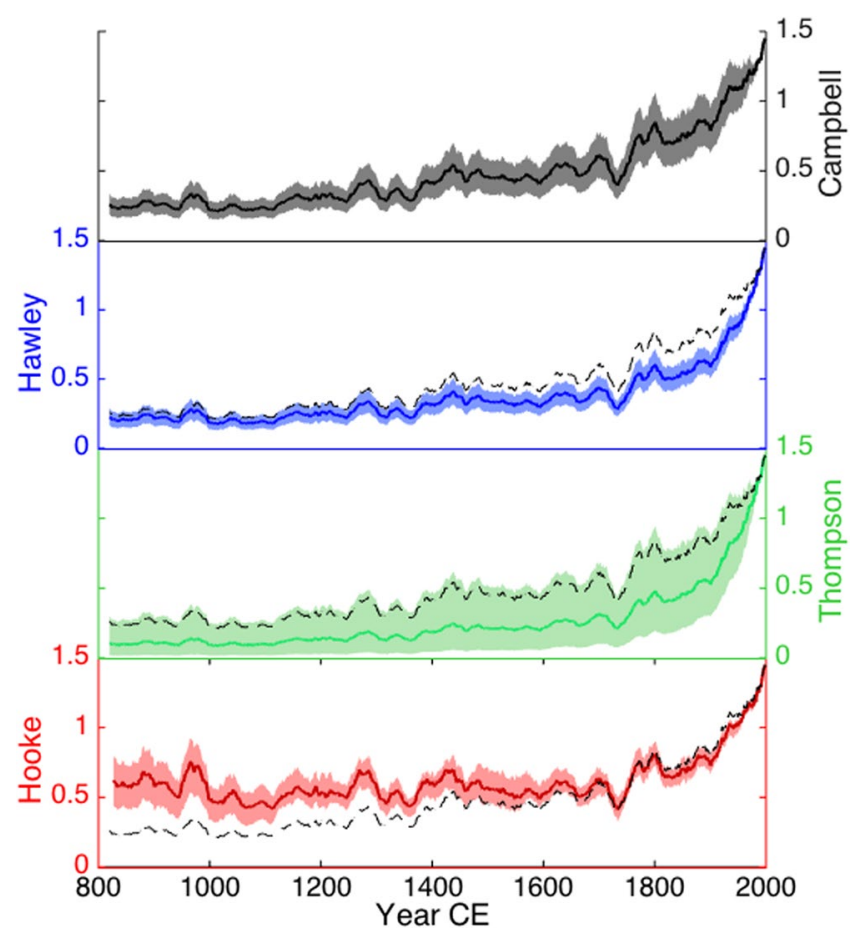

Figure 3. Accumulation rate time series from $810 \mathrm{CE}$ to the present after correction by four independent layerthinning model approaches: Campbell ${ }^{14}$ (black), Hawley (blue), Thompson ${ }^{13,18-20}$ (green) and Hooke ${ }^{12}$ (red); see supplementary information for details about each. Y-axes are equivalent in each panel, ranging from 0 to 1.5 meters of water equivalent annual accumulation. Results are smoothed with a 21-year running mean for clarity. Shading indicates the full range of accumulation estimates produced among different scenarios in each model. The central estimate in the Campbell model is shown for comparison in the bottom three panels as a dotted line. Every model shows unprecedented levels of snow accumulation in the $20^{\text {th }}$ century under any set of plausible input parameters.

seasonal parsing and overall fidelity of the Denali accumulation record. Furthermore, the south coastal Alaska station records and the wintertime ice core accumulation record all show the distinct 1976/77 step increase in precipitation associated with the PDO transition from a negative to a positive mode $8,9,23,24$ (Fig. 4E). However, while 


\begin{tabular}{|l|l|l|l|l|}
\hline Station & $\begin{array}{l}\text { Number of } \\
\text { Years }\end{array}$ & Annual & Summer & Winter \\
\hline Anchorage & 60 & $\mathbf{0 . 2 7}$ & 0.25 & 0.23 \\
\hline Fairbanks & 64 & 0.01 & 0.13 & $-\mathbf{0 . 3 1}$ \\
\hline Talkeetna & 94 & 0.12 & $\mathbf{0 . 3 0}$ & -0.06 \\
\hline Cordova & 63 & 0.15 & 0.11 & 0.19 \\
\hline Gulkana & 67 & 0.04 & 0.08 & 0.00 \\
\hline Juneau & 63 & 0.25 & -0.06 & 0.38 \\
\hline Kodiak & 63 & $\mathbf{0 . 4 7}$ & 0.07 & $\mathbf{0 . 5 9}$ \\
\hline Sitka & 60 & 0.02 & 0.03 & 0.17 \\
\hline Valdez & 95 & $\mathbf{0 . 2 5}$ & -0.10 & $\mathbf{0 . 4 0}$ \\
\hline Yakutat & 95 & 0.12 & -0.07 & $\mathbf{0 . 3 0}$ \\
\hline King Salmon & 84 & 0.09 & 0.06 & 0.02 \\
\hline Tanana & 94 & $\mathbf{- 0 . 0 1}$ & 0.15 & $\mathbf{0 . 3 0}$ \\
\hline Bethel & 88 & $\mathbf{0 . 2 3}$ & 0.22 & -0.03 \\
\hline Nome & 63 & 0.13 & 0.15 & 0.14 \\
\hline Homer & 81 & $\mathbf{0 . 3 3}$ & 0.20 & $\mathbf{0 . 4 3}$ \\
\hline Iliamna & 70 & $\mathbf{0 . 3 6}$ & $\mathbf{0 . 3 6}$ & 0.20 \\
\hline Kenai & 68 & 0.13 & $\mathbf{0 . 3 4}$ & 0.14 \\
\hline McKinleyPark & 88 & 0.07 & 0.09 & $\mathbf{- 0 . 1 6}$ \\
\hline Palmer & 63 & $\mathbf{0 . 4 6}$ & 0.14 & $\mathbf{0 . 3 1}$ \\
\hline Seward & 103 & $\mathbf{0 . 4 4}$ & $\mathbf{0 . 2 4}$ & $\mathbf{0 . 5 5}$ \\
\hline & & & & \\
\hline
\end{tabular}

Table 1. Correlations between accumulation data in the Mt. Hunter ice core and precipitation at regional meteorological stations. Correlation values ( $r$ ) between the ice core and meteorological station data are calculated annually, during summer (MJJA), and during winter (SONDJFMA) over their respective periods of record. Values significant to $95 \%$ are printed in bold. Data obtained using Climate Reanalyzer (http://ccireanalyzer.org), Climate Change Institute, University of Maine.

the weather station records show a step increase in precipitation during the late 1970s, the Denali accumulation record shows that winter precipitation continued to rise on Mt. Hunter after the 1976 shift. We revisit this point in the discussion section below.

Summer accumulation in the Denali record has a more muted but still significant $(\mathrm{p}<0.001)$ increase of $1.2 \mathrm{~mm} \mathrm{a}^{-2}$ since 1867, or a total rise of $49 \%$ over this interval (Fig. 2). Correlations between the ice core record and Alaskan stations during summer months are restricted to nearby stations in South Central Alaska, including Talkeetna, Homer, Bethel, Iliamna, Kenai, and Seward (Table 1). The summer increase also has a different timing from the wintertime record, characterized by an increase between 1905 and 1925 and relative stability throughout the remainder of the record (Fig. 2 inset). Because of the high temporal resolution ( $\geq 8$ samples/year) during the last century, the timing of the increases in summer and winter precipitation are robust to seasonal partitioning.

Central Alaska has warmed by $2-3^{\circ}$ since $1950^{8}$, and higher precipitation is expected from higher temperatures through the Clausius-Clapeyron (C-C) increase in absolute humidity ${ }^{3}$. While likely responsible for some of the precipitation increase on Mt. Hunter, the observed warming is insufficient to account for most of the doubling of precipitation recorded in the Denali ice core, even with enhanced $\left(14 \% \mathrm{~K}^{-1}\right) \mathrm{C}$-C scaling rates over mountainous regions ${ }^{25}$.

It is very likely that that a strengthening Aleutian Low is responsible for the majority of the accumulation increase observed in the Mt. Hunter ice core. This is supported by the strong relationship between winter Denali accumulation and winter precipitation recorded in weather stations along the Gulf of Alaska, which are sensitive to changes in Aleutian Low strength ${ }^{26}$. Wetter winters in the Mt. Hunter ice core record between 1910-2010 were significantly associated with a deeper Aleutian Low at the surface $(\mathrm{p}<0.05$; Fig. S4) and $500 \mathrm{mb}$ level $(\mathrm{p}<0.1$; Fig. 4A) in NCEP/NCAR $20^{\text {th }}$ century reanalysis data ${ }^{27}$. The $500 \mathrm{mb}$ anomalies include a downstream enhanced ridge over western North America and deeper low over the southeast United States characteristic of the PNA positive teleconnection pattern ${ }^{28}$ (Fig. $4 \mathrm{~A}-\mathrm{B}$ ). The correlation between the PNA index and winter Denali accumulation from 1950 to 2010 is $r=0.64$ ( $p<0.0001$; Fig. 4E), consistent with a strong relationship between increasing Mt. Hunter snow accumulation and an intensifying Aleutian Low. A $20^{\text {th }}$ century strengthening Aleutian Low is also supported by a significant negative trend in the North Pacific Index (NPI), a sea-level pressure index over the Aleutian Low region ${ }^{29}$. The negative trend in NPI index during SONDJFMA is significant to $\mathrm{p}<0.02$, and during DJF is significant to $\mathrm{p}<0.01$. Previous work indicates that the strength of the Aleutian Low tends to co-vary with its mean position, with a stronger (weaker) Aleutian Low shifted towards the east (west) ${ }^{30,31}$. However, our observations show that the highest accumulation winters on Mt. Hunter are associated with a sea level pressure anomaly centered over the Aleutian Islands (Fig. S4). Thus, we observe no strong evidence for covariance between Aleutian Low position and Mt. Hunter snowfall. 

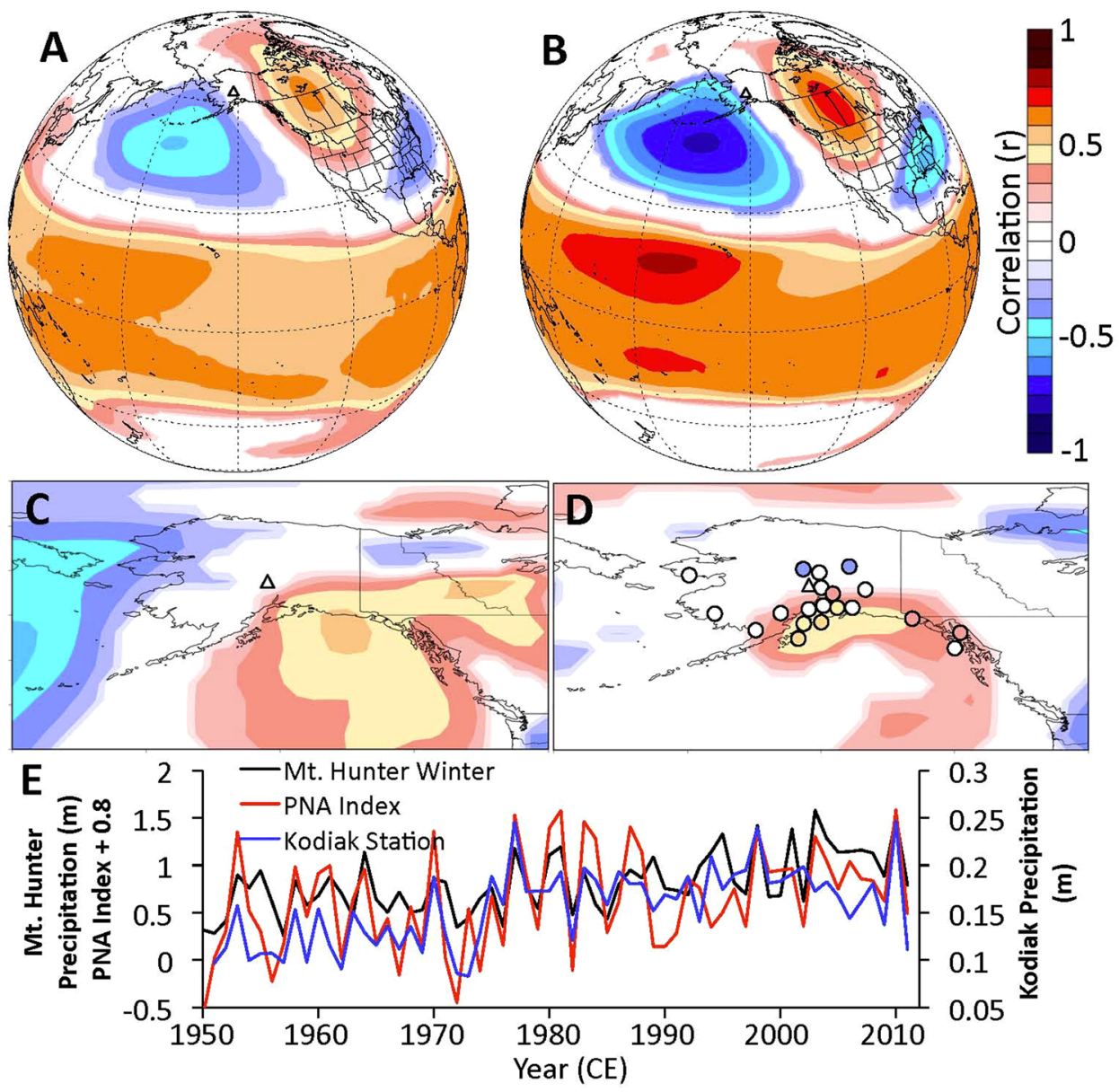

Figure 4. Climatological correlations with winter accumulation on Mt. Hunter. (A-D) Spatial Pearson correlations between (A) $20^{\text {th }}$ Century reanalysis ${ }^{27}$ DJF $500 \mathrm{mb}$ geopotential heights and Mt. Hunter (triangle) winter accumulation from 1910-2010; (B) reanalysis DJF $500 \mathrm{mb}$ geopotential heights and September-April PNA index from 1950-2010; (C) reanalysis DJF surface meridional winds and Mt. Hunter winter accumulation; (D) Mt. Hunter winter accumulation and reanalysis DJF precipitation (color shading) and September-April precipitation recorded at Alaskan weather stations (color-filled circles). Colors only filled in areas exceeding 90\% significance. (E) Time series of Mt. Hunter winter accumulation (black), the PNA index (red), and Kodiak precipitation (blue) for September-April from 1950-2011. Images obtained using Climate Reanalyzer (http:// cci-reanalyzer.org), Climate Change Institute, University of Maine, USA.

\section{Discussion}

Under all four ice-thinning models, the Mt. Hunter snow accumulation rates in the $20^{\text {th }}$ century are unprecedented in the last millennium (Figs 2, 3). The Campbell finite element ice flow model ${ }^{14}$ produces the highest degree of thinning since $1650 \mathrm{CE}$ among any of the model simulations we used, and therefore is the most conservative model in that it produces the smallest precipitation increase on Mt. Hunter since 1840 CE. This is our preferred ice flow model because it is constrained by the detailed basin and glacier geometry, spatial accumulation patterns, and surface ice velocity of the Mt. Hunter ice core drill site. Prior to 1650, the Hooke model ${ }^{12}$ consistently produces higher accumulation values than the other thinning models (Fig. 3). This may be because parameters in the Hooke model are statistically optimized to match the timescale, as opposed to the other three models where thinning corrections are based on explicit calculations of vertical strain rate (see Supplemental Information). Even in the Hooke model, the accumulation rates before 1840 never approach $20^{\text {th }}$ century values (Fig. 3).

Numerous accumulation reconstructions from alpine ice cores have been published during recent decades. Mt. Hunter is very similar to many of these sites with low velocities near the drill site (approximately $2 \mathrm{~m} \mathrm{a}^{-1}$ ), surface-conformable stratigraphy, and very low surface slope. The average annual temperature on Mt. Hunter $\left(-17^{\circ} \mathrm{C}\right)$ is cooler than at most other alpine ice core sites but is similar to Ushkovsky volcano ${ }^{32}\left(-15.7^{\circ} \mathrm{C}\right)$ and Dasuopu glacier ${ }^{33}\left(-16^{\circ} \mathrm{C}\right)$. Many other alpine ice core accumulation records have been drilled at sites with saddle-like geometry including Aurora Peak ${ }^{16}$, Mt. Waddington ${ }^{21}$, Mt. Everest ${ }^{12}$, Belukha Saddle ${ }^{34}$ and Mt. Logan ${ }^{15}$. Thus, we would expect that the modeling approaches published in these studies would be applicable to the conditions on Mt. Hunter. Nevertheless, we use four different modeling approaches, one of which is designed for the specific Mt. Hunter site geometry, and all of which have very conservative and rigorously quantified ranges 
of uncertainty (Fig. 3 and Supplemental Information). To our knowledge, no other alpine ice core accumulation record has been developed with such a thorough characterization of the thinning regime or uncertainties. All of the thinning models produce a robust increase in accumulation since the mid-1 $9^{\text {th }}$ century above late-Holocene background values.

While all of our modeling simulations agree that during the early half of our record (810-1400 CE) precipitation remained well below present values, we cannot confidently conclude from our results whether precipitation was increasing or decreasing within this time period. One simulation (the Hooke model ${ }^{12}$ ) shows a slight decrease in accumulation rate between 810 and $1400 \mathrm{CE}$ while the remaining three modeling approaches suggest a slight accumulation increase during this period with superimposed decadal to centennial scale variability. Relatively low snow accumulation on Mt. Hunter between 1000 and $1300 \mathrm{CE}$ is consistent with low sodium concentrations in the Mt. Logan and Mt. Hunter records during this interval, indicative of a relatively weak Aleutian Low (Fig. S5) ${ }^{35,36}$.

We suggest that the recent doubling of Alaska Range snowfall recorded in the Denali ice core reflects an increase in absolute humidity with warming and an intensification of the Aleutian Low to its strongest levels (most positive PNA) of the past millennium. The precipitation increase we observe on Mt. Hunter is apparent in other Alaskan records. Between the mid $-20^{\text {th }}$ century and present day, several weather stations along coastal Alaska $^{6}$ (e.g. Kodiak, Palmer, Juneau) have experienced similar (but smaller) increases in wintertime precipitation compared with Mt. Hunter (Fig. S6). Consistent with our results, a century-long ice core collected from Aurora Peak in the eastern Alaska Range ${ }^{16}(240 \mathrm{~km}$ from Mt. Hunter) also records a doubling of snow accumulation over the $20^{\text {th }}$ century, with greater rates of precipitation increase than observed on Mt. Hunter (Figs S5, S6). The Mt. Logan ice core (Yukon, Canada) time series of accumulation, sodium, and water isotope ratios show trends over the past 200 years indicative of a strengthening Aleutian Low ${ }^{15,35,37}$ (Fig. S5). Specifically, Moore et al. ${ }^{15}$ found a positive and accelerating trend in Mt. Logan annual accumulation after the middle of the nineteenth century, and interpret it as indicative of a progressively more positive PNA. This was supported by Rupper et al. ${ }^{38}$ who confirm that high accumulation years on Mt. Logan are associated with a stronger wintertime Aleutian Low. Furthermore, the composite Mt. Logan and Mt. Hunter sea-salt $\mathrm{Na}^{+}$calibrated Aleutian Low proxy similarly supports a progressive strengthening of the Aleutian Low over recent centuries to its strongest levels of the past 1500 years $^{36}$ (Fig. S5).

The doubling of accumulation rates at Mt. Hunter, Aurora Peak and other sites near the Gulf of Alaska stand seemingly in contrast to the more modest $2-3 \%$ increases in precipitation per degree of warming predicted by climate models (e.g. Held and Soden ${ }^{3}$ ). The rapid precipitation increase in Alaska represents a regional signal amplified primarily by enhanced advection of moisture and storms into the Gulf of Alaska associated with a strengthening Aleutian Low. With a deeper Aleutian Low, the largest precipitation increases would be expected to occur where southerly flow on the eastern side of the low encounters the Alaskan coastline and mountain ranges. This is exactly the pattern we observe, with increasing precipitation at coastal Alaskan weather stations including Kodiak, Juneau and Valdez, and the strongest precipitation increases at orographic barriers such as Mt. Hunter and Aurora Peak (Fig. 4d; Fig. S6). Previous work has shown that this configuration leads to drier conditions within the rain shadow of these orographic barriers ${ }^{39}$, which is apparent as negative correlations between winter Mt. Hunter accumulation and precipitation at Tanana, McKinley Park, and Fairbanks located north of the Alaska Range (Table 1). Additionally, Tanana winter precipitation has experienced a significant decrease since $1950^{6}$. We do not, therefore, infer that the Mt. Hunter precipitation increase is representative of the expected broader mid-high latitude precipitation increase predicted by global scale climate projections ${ }^{40}$. Rather, the Mt. Hunter record captures a specific regional phenomenon (a deepening Aleutian Low) that has occurred in conjunction with warming, resulting in a dramatic increase in regional precipitation. Finally, ice core ${ }^{17}$ and other paleoproxy records ${ }^{41}$ from outside the North Pacific region do not document long-term precipitation increases, consistent with our finding that the North Pacific hydroclimate intensification is a regional feature associated with a strengthening Aleutian Low.

Dynamical studies suggest that the most plausible way to intensify the Aleutian Low is through warmer tropical SSTs, particularly in the western tropical Pacific and Indian Oceans ${ }^{42}$. Enhanced convective precipitation and latent heat release associated with higher tropical Pacific and Indian Ocean SSTs induce a Rossby wave extratropical response manifesting as the PNA positive pattern ${ }^{42,43}$ (Fig. $4 \mathrm{~b}$ ). Consistent with this dynamical theory, the annual Mt. Hunter accumulation record from $1910-2010$ is significantly correlated $(r=0.59, p<0.01)$ with reanalysis SSTs in the western tropical Pacific and Indian Oceans (Fig. 5), supporting a strong link between Alaskan precipitation and tropical SSTs. This high correlation is due in part to the highly trended nature of both records, with warming temperatures over the tropical Pacific and Indian Oceans and rising accumulation in the Alaska Range. However, a significant correlation remains after detrending both time series $(r=0.39, \mathrm{p}>0.01)$, demonstrating the robust nature of the link between the tropical Pacific and Indian Ocean and North Pacific climate identified by previous studies ${ }^{42,43}$.

In Fig. 6, we compare the Denali accumulation record to multiproxy records of SSTs in the Western Pacific and Indian Oceans ${ }^{44,45}$. Sustained and significant changes since $\sim 1840 \mathrm{CE}$ are evident in each dataset (Denali $=1840$ $\mathrm{CE}$, Western Pacific $=1834 \mathrm{CE}$, Indian $=1827 \mathrm{CE}$ ), which we confirm using the change detection methods described in Abram et al. ${ }^{44}$ (see Methods). This is consistent with the doubling of Denali snow accumulation since $\sim 1840$ being forced, at least in part, by warmer western Pacific and Indian Ocean SSTs through the atmospheric bridge $^{43}$. The secular increase in Denali and Mt. Logan ice core sea salt $\mathrm{Na}^{+}$concentrations over recent centuries has also been interpreted as an extratropical response to warming Pacific SSTs ${ }^{35,36}$, as has a dramatic increase in the Mt. Logan $\delta^{18} \mathrm{O}$ record at $1840^{37}$ (Fig. S5). Similarly, a proxy record of Hawaii precipitation includes a secular change towards more PNA positive conditions, reflected as a long-term precipitation decrease (Fig. 6) associated with anomalously high pressure in the subtropical North Pacific ${ }^{46}$ (Fig. 4b). Thus, through the atmospheric 

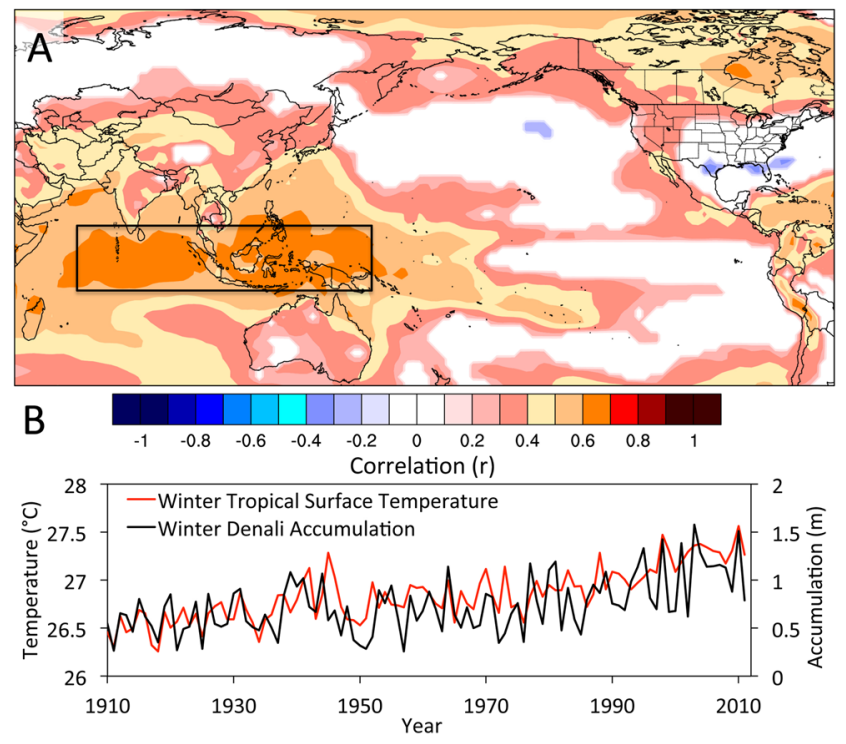

Figure 5. Relationship between tropical Pacific and Indian Ocean temperatures and accumulation on Mt. Hunter (triangle). (A) Spatial correlation between annual Mt. Hunter accumulation and annual surface temperature. (B) Time series of wintertime western tropical Pacific and Indian Ocean temperatures compared to Mt. Hunter wintertime accumulation. 20th Century Reanalysis V2 data ${ }^{27}$ from 1910-2010 is used in each panel. The black box delineates the Indian and western tropical Pacific Ocean region averaged in panel B. Colors only filled in areas exceeding 90\% significance. Images obtained using Climate Reanalyzer (http://cci-reanalyzer. org), Climate Change Institute, University of Maine, USA.

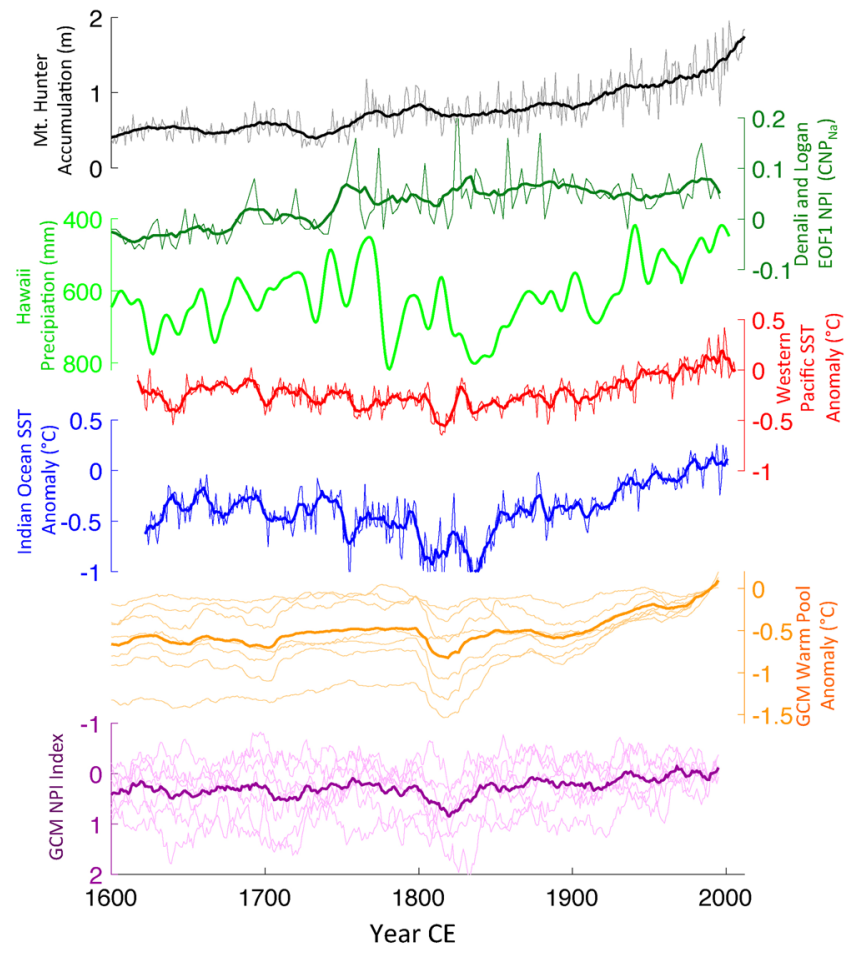

Figure 6. Paleoclimate context for Mt. Hunter precipitation increase. The Mt. Hunter annual accumulation time series (light grey) with a 21-year running mean (solid black) compared with reconstructed Hawaii rainfall $^{46}$ (green), Western Pacific (red) and Indian Ocean (blue) SST anomalies ${ }^{44,45}$, and 21-year running mean GCM reconstructions of Western Pacific temperature anomalies (orange), and the NPI index (purple) from the CMIP5 Last Millennium experiments. With the exception of the GCM reconstructed NPI index, each dataset shows a sustained directional trend from the early 1800 s to the present. 
teleconnection, warmer western tropical Pacific and Indian Ocean waters have supported an increase in Alaskan precipitation and a concomitant decrease in Hawaiian precipitation.

Inspection of Fig. $5 \mathrm{~b}$ reveals that both the western tropical Pacific-Indian Ocean SSTs and Mt. Hunter wintertime accumulation have continued to progressively increase since the 1976/77 PDO transition. This post-1977 increase contrasts with steady wintertime precipitation at south coastal Alaska weather stations following the precipitation jump in 1976/77 (Fig. 4E). This may indicate a heightened sensitivity to tropical SST teleconnections at higher elevation in Alaska. Other studies from the nearby St. Elias range have inferred a similar sensitivity of high elevation hydroclimate to conditions in the tropical Pacific Ocean ${ }^{35,37}$. The Rossby waves responsible for these tropical teleconnections are best defined in the free troposphere ${ }^{43}$, which may explain the preferential expression of tropical connections at high altitudes in Alaska. Additionally, mountain summit areas are more representative of free-air conditions compared to stations located in valleys or along the coast where local effects may mask the tropical climate signal ${ }^{47}$.

We examined output from seven CMIP5 GCM simulations (Table S1) to assess whether Last Millennium Experiment reconstructions capture the Aleutian Low intensification we infer from the Mt. Hunter record. All of the GCM simulations show warming in the western Pacific $\left(15^{\circ} \mathrm{S}-15^{\circ} \mathrm{N}, 110^{\circ}-160^{\circ} \mathrm{E}\right)$ with an ensemble average warming of $0.57^{\circ} \mathrm{C}$ during the last two centuries comparing well with the $0.5^{\circ}$ warming estimate from paleoclimate records ${ }^{45}$. In contrast, only 3 of the 7 models show significant $(\mathrm{p}<0.05)$ deepening of the Aleutian Low (defined by the NPI index) (Fig. 6). None of the models match the observed increase in precipitation over the central Alaska Range or southern Alaska $\left(58^{\circ}-62^{\circ} \mathrm{N}, 135^{\circ}-155^{\circ} \mathrm{W}\right)$, nor does the ensemble show a consistent precipitation decrease in Hawaii (Fig. S7). Those models that do suggest a precipitation increase in southern Alaska (MPI-ESM ${ }^{48}$ and IPSL-CM5A-LR ${ }^{49}$ ) produce a 5-10\% rise in precipitation during the last two centuries, considerably less than shown in the Denali accumulation record. Furthermore, these two models are both among the simulations that generate an Aleutian Low deepening since 1840, and have the greatest increase in Western Pacific SSTs, although the SST increase in both models is significantly larger than in proxy reconstructions ${ }^{45}$. We suggest that current GCMs underestimate the sensitivity of North Pacific atmospheric teleconnections to tropical SSTs, and thus further model development focused on improving the extra-tropical responses to tropical SST warming may improve North Pacific hydroclimate projections in a warming world.

Although the future response of central-eastern tropical Pacific SSTs to increased radiative forcing remains unclear $^{50}$, GCM simulations show enhanced ocean warming in the western tropical Pacific and Indian Ocean through the $21^{\text {st }}$ century in response to higher GHG concentrations $s^{51,52}$. The Mt. Hunter accumulation record corroborates and significantly extends instrumental (Fig. 4) and paleoclimate ${ }^{15,16}$ records showing precipitation increases in southern Alaska during the $20^{\text {th }}$ century. While hemispheric-scale reconstructions have yet to reveal coeval intensification of $20^{\text {th }}$ century hydroclimate anomalies outside of the North Pacific ${ }^{41}$, our data imply that regions such as Mt. Hunter, which are sensitive to tropical teleconnections, may continue to experience hydroclimate variability well outside the natural range of the past millennium.

\section{Methods}

Ice Core Collection and Processing. The Mt. Hunter ice cores were drilled in 2013 at 3,900 meters elevation from the saddle between the north and middle peaks of Mt. Hunter. Two $8 \mathrm{~cm}$ diameter cores were drilled to bedrock (208 $\mathrm{m}$ deep) using a Badger-Eclipse ice drill. After drilling, ice cores were shipped to the National Ice Core Laboratory in Denver, Colorado where the cores were weighed and measured for density calculations at $\sim 1 \mathrm{~m}$ resolution, and cut into $3 \times 3 \mathrm{~cm}$ sticks for melting at Dartmouth.

Laboratory Procedures. The ice cores were continuously sampled on the Dartmouth Ice Core Melter system, which features an ultra-clean silicon carbide melt head that separates potentially contaminated meltwater from the outside of the core and pristine meltwater from the core interior ${ }^{53}$. The water from the interior fraction was pumped through an Abakus (Klotz) laser particle counter and particle size analyzer, a liquid conductivity meter (LCM) and finally into pre-cleaned vials for chemical analyses ${ }^{54}$. Denali core 2 was sampled and analyzed back to $190 \mathrm{~m}$ depth $(800 \mathrm{CE})$, while only the top $133 \mathrm{~m}$ (1870 CE) were sampled and analyzed from core 1 to duplicate the critical instrumental period. Of the 190 meters of core 2 analyzed for this study, only 2.23 meters of ice had low core quality and excessive fracturing (170.58-171.68 m, 20 years; $179.70-180.11 \mathrm{~m}, 10$ years; $181.56-$ $181.72 \mathrm{~m}, 5$ years; $185.02-185.44 \mathrm{~m}, 24$ years; $187.76-187.88 \mathrm{~m}, 7$ years; $189.50-189.59 \mathrm{~m}, 5$ years) and could not be sampled using the continuous melter system. These sections were instead sampled discretely for stable water isotopes only.

Ice core melter samples were collected at a resolution averaging $5 \mathrm{~cm}$, depending on melt rate, except that isotope samples were collected at $\sim 1 \mathrm{~cm}$ resolution from 1750 to $1250 \mathrm{CE}$. LCM and particle concentration and size distribution were measured at an effective resolution of 1 millimeter. Major ion concentrations were measured on a Dionex 5000 capillary ion chromatograph (IC). Each IC analysis run of 50 samples included two sets of anion and cation standards for each analyte as well as four clean water blanks directly from the MilliQ filtration system, two blanks of MilliQ water from the bottle used to flush the lines in the melter system, and three blanks of MilliQ water that has been run through the melter head and the entire system. Water isotope ratios were measured by a Picarro L2130i Cavity Ring Down Spectrometer linked to a high throughput vaporizer at the University of Maine. Results are reported relative to SMOW (Standard Mean Ocean Water). Long-term precision is $0.1 \%$ o $(1 \sigma)$ for $\delta^{18} \mathrm{O}$ and $0.4 \% 0(1 \sigma)$ for $\delta \mathrm{D}$, based on multiple analyses of internal and international standards.

Ice Core Dating. To develop the Denali ice core timescale, three experienced researchers (D.W., E.O., D.F.) independently counted annual layers in the Mt. Hunter ice core chemical data. The timescale to $1777 \mathrm{CE}$ was determined by counting annual oscillations in $\delta^{18} \mathrm{O}$ (summer peak), melt layers (summer peak), magnesium (spring peak), dust (spring peak), liquid conductivity (summer peak), ammonium (summer peak) and 
methanesulfonic acid (MSA; late summer-fall peak), consistent with previous North Pacific ice cores ${ }^{16,21,35,55-57}$. Using the relative peak positions of MSA in the late summer-fall and magnesium in the spring we distinguish cold-season (September-April) and warm-season (May-August) snow accumulation on Mt. Hunter back to 1867 $\mathrm{CE}$. The timescale from 1777 to $1500 \mathrm{CE}$ is based on annual oscillations of $\delta^{18} \mathrm{O}, \delta \mathrm{D}$, deuterium excess, dust and liquid conductivity measurements that were made at higher resolution than the other analytes, while conductivity and dust concentration measurements were exclusively used to date the ice core from 1500-800 CE.

The Mt. Hunter chronology is validated from 1750-2013 CE by comparing the timing of peaks in sulfate, chloride and conductivity to the known dates of explosive volcanic eruptions ${ }^{53,58,59}$ (Fig. S2). The volcanic events are used only as validation of our layer counting efforts and the timescale was not forced to match any particular event. There is no offset between our timescale and known volcanic eruptions as indicated by peaks in sulfate, chloride and conductivity during the $19^{\text {th }}$ and $20^{\text {th }}$ centuries, indicating a precision within $+/-1$ year throughout the last 200 years. The volcanoes in the $18^{\text {th }}$ century used for chronology validation (Laki, 1784 and Pavlof, 1763) were offset by one year from our chronology. Additionally, Cs-137 concentrations in the Mt. Hunter core strongly peak in 1963 during the largest atmospheric nuclear weapons testing campaign, which closely matches other published data ${ }^{16,56}$.

Accumulation Uncertainty. Errors in the reported accumulation values (Y direction in Fig. 2) are due to three factors. First, there is uncertainty due to spatial and stochastic processes including wind redistribution, which we quantify using the difference in layer thicknesses between the primary and secondary ice cores. The layer thickness records from the two cores have a correlation coefficient of 0.92 and a slope of 0.96 . During the last 100 years, the average percent difference in annual accumulation between the two cores is $10.2 \%$, which we assume is consistent throughout the core and which we refer to as "stochastic error".

There is a range of depths for each January 1 position because the three layer counters picked slightly different spots due to abnormal peak shapes, ambiguity, dispersion and human error. For each annual layer, the so-called "Peak Position Error" is quantified by dividing the range in January 1 position by the annual layer thickness. In cases where only two of the three counters picked a year, we assign an uncertainty of $+/-50 \%$ of the annual layer thickness to that year. In cases where the core was damaged and equally spaced years were assigned, the uncertainty range is defined as the difference between the thinnest and thickest layers within 10 years of the gap. Peak position error is generally equal to about $10 \mathrm{~cm}$ (w. eq.) in the final thinning-corrected accumulation record, although it is occasionally larger in sections of low core quality when uncertainty assignments of $+/-50 \%$ are more common.

As described in detail in the Supporting Information, we use four ice flow models to quantify the level of uncertainty in accumulation rate arising from the choice of flow model for layer thinning correction. For each year we define the "modeling error" as the entire range between the minimum and maximum model runs.

Stochastic error and peak position error are assumed to be symmetrically distributed around a single mean accumulation value and are aggregated using Eq. 1,

$$
U_{t}=\sqrt{\frac{S_{t}^{2}+P_{t}^{2}}{2}}
$$

where $U_{t}$ is the total uncertainty in year $t, S_{t}$ is stochastic uncertainty and $P_{t}$ is peak position uncertainty. We then define our upper and lower uncertainty bounds by adding $U_{t}$ to the maximum uncertainty bound from our flow modeling simulations, and subtracting $U_{t}$ from our minimum flow modeling uncertainty bound. This analysis shows that it is virtually certain that accumu lation on Mt. Hunter has never approached its present day values at any time in the last millennium.

Analysis of Instrumental and Reanalysis Data. Alaska weather station data were obtained from the Global Historical Climatology Network ${ }^{6}$ and accessed through the Climate Change Institute Climate Reanalyzer. Months with missing precipitation data were filled with the average value for that month over the period of record. Reanalysis datasets were accessed through the Climate Change Institute Climate Reanalyzer website as well as the NCEP/NCAR monthly composites website. We use NCEP/NCAR $20^{\text {th }}$ century reanalysis data ${ }^{27}$ because of the long dataset duration. We restrict our analysis to the last 100 years (1910-2010) since both the resolution of our seasonal accumulation record and the reliability of the reanalysis data are higher after 1910.

Change Point Detection. Following Abram et al. ${ }^{44}$, we define the point of sustained and significant increase in our time series as the point at which trends significant at $\mathrm{p}<0.1$ persist through present day. We used SiZer analysis with code from Abram et al. ${ }^{44}$ that was developed from Hannig and Marron ${ }^{60}$ and Chaudhury and Marron ${ }^{61}$. Using this technique, the average rate of accumulation change is calculated across moving windows ranging from 15 to 50 years, effectively removing high frequency variations from the timeseries to varying degrees. For Mt. Hunter, $1840 \mathrm{CE}$ is the median date (among the different degrees of smoothing) at which all subsequent accumulation rates trends remain positive. Input data were annually sampled except for reconstructed Hawaii precipitation ${ }^{46}$, which is only available after 21 -year smoothing. For consistency, analysis was conducted between 1625 CE and 2000 CE for each dataset.

Global Climate Model Output. To compare our results with CMIP5 GCM simulations ${ }^{48,49,62-66}$, we obtained GCM output of sea level pressure and precipitation rate over the Alaska region over the duration of our study. GCM data were accessed through the Earth System Grid Federation data node https://pcmdi.llnl.gov/esgf-idp. There were seven GCMs available with data spanning the period from 1000-2005 CE and each of these is described in Table S1. 
We calculated the average monthly sea level pressure values over the area from $160^{\circ} \mathrm{E}$ to $140^{\circ} \mathrm{W}$ and $30^{\circ} \mathrm{N}$ to $65^{\circ} \mathrm{N}$ in order to reconstruct the North Pacific Index (NPI) as defined in Trenberth and Hurrell ${ }^{28}$. We used GCM output from September-April to match our winter accumulation record. Sea surface temperature is not available across all seven GCM ensembles so we use surface air temperature from $15^{\circ} \mathrm{S}-15^{\circ} \mathrm{N}, 110^{\circ}-160^{\circ} \mathrm{E}$ as an indicator of surface conditions over the Western Pacific warm pool. Results are standardized relative to the 1980-2000 mean. We extracted monthly precipitation rate output from the GCMs over the Western Pacific $\left(15^{\circ} \mathrm{S}-15^{\circ} \mathrm{N}\right.$, $\left.110^{\circ}-160^{\circ} \mathrm{E}\right)$, Hawaii $\left(15^{\circ}-25^{\circ} \mathrm{N}, 155^{\circ}-170^{\circ} \mathrm{W}\right)$, Southern Alaska $\left(58^{\circ}-62^{\circ} \mathrm{N}, 135^{\circ}-155^{\circ} \mathrm{W}\right)$ and Mt. Hunter $\left(63^{\circ} \mathrm{N}, 151^{\circ} \mathrm{W}\right)$, and combined the data into annual and seasonal averages (Fig. S7).

\section{References}

1. Stocker, T. F. et al. Climate change 2013: The physical science basis. (Cambridge University Press Cambridge, UK, and New York, 2014).

2. Sarojini, B. B., Stott, P. A. \& Black, E. Detection and attribution of human influence on regional precipitation. Nature Climate Change (2016).

3. Held, I. M. \& Soden, B. J. Robust responses of the hydrological cycle to global warming. Journal of Climate 19, 5686-5699 (2006).

4. Greve, P. et al. Global assessment of trends in wetting and drying over land. Nat. Geosci. 7, 716-721 (2014).

5. L'Heureux, M. L., Mann, M. E., Cook, B. I., Gleason, B. E. \& Vose, R. S. Atmospheric circulation influences on seasonal precipitation patterns in Alaska during the latter 20th century. J. Geophys. Res.-Atmos. 109, 17, https://doi.org/10.1029/2003jd003845 (2004).

6. Lawrimore, J. H. et al. An overview of the Global Historical Climatology Network monthly mean temperature data set, version 3. Journal of Geophysical Research: Atmospheres 116 (2011).

7. Mantua, N. J., Hare, S. R., Zhang, Y., Wallace, J. M. \& Francis, R. C. A Pacific interdecadal climate oscillation with impacts on salmon production. Bull. Amer. Meteorol. Soc. 78, 1069-1079, https://doi.org/10.1175/1520-0477 (1997).

8. Hartmann, B. \& Wendler, G. The significance of the 1976 Pacific climate shift in the climatology of Alaska. Journal of Climate 18, 4824-4839, https://doi.org/10.1175/jcli3532.1 (2005)

9. McAfee, S. A., Guentchev, G. \& Eischeid, J. K. Reconciling precipitation trends in Alaska: 1. Station-based analyses. J. Geophys. Res.Atmos. 118, 7523-7541, https://doi.org/10.1002/jgrd.50572 (2013).

10. Cuffey, K. M. \& Paterson, W. S. B. The physics of glaciers. (Academic Press, 2010)

11. Glen, J. W. The flow law of ice: A discussion of the assumptions made in glacier theory, their experimental foundations and consequences. IASH Publ 47, 171-183 (1958).

12. Kaspari, S. et al. Snow accumulation rate on Qomolangma (Mount Everest), Himalaya: synchroneity with sites across the Tibetan Plateau on 50-100 year timescales. J. Glaciol. 54, 343-352 (2008).

13. Thompson, L. G. et al. Geophysical investigations of the tropical Quelccaya ice cap, Peru. J. Glaciol. 28, 57-69 (1982).

14. Campbell, S. et al. Strain-rate estimates for crevasse formation at an alpine ice divide: Mount Hunter, Alaska. Ann. Glaciol. 54, 200-208, https://doi.org/10.3189/2013AoG63A266 (2013).

15. Moore, G. W. K., Holdsworth, G. \& Alverson, K. Climate change in the North Pacific region over the past three centuries. Nature 420, 401-403, https://doi.org/10.1038/nature01229 (2002).

16. Tsushima, A. et al. Reconstruction of recent climate change in Alaska from the Aurora Peak ice core, central Alaska. Clim. Past 11, 217-226, https://doi.org/10.5194/cp-11-217-2015 (2015).

17. Mosley-Thompson, E., Thompson, L. G., Dai, J., Davis, M. \& Lin, P. N. Climate of the last 500 years: High resolution ice core records. Quat. Sci. Rev. 12, 419-430 (1993).

18. Thompson, L. G. et al. A 25,000-year tropical climate history from Bolivian ice cores. Science 282, 1858-1864 (1998).

19. Thompson, L. G. O. et al. Holocene-late Pleistocene climatic ice core records from Qinghai-Tibetan Plateau. Science 246, 474-477 (1989).

20. Thompson, L. G. O. et al. Tropical climate instability: The last glacial cycle from a Qinghai-Tibetan ice core. Science 276, 1821-1825 (1997).

21. Neff, P. D. et al. Ice-core net snow accumulation and seasonal snow chemistry at a temperate-glacier site: Mount Waddington, southwest British Columbia, Canada. J. Glaciol. 58, 1165-1175, https://doi.org/10.3189/2012JoG12J078 (2012).

22. Sen, P. K. Estimates of the regression coefficient based on Kendall's tau. Journal of the American Statistical Association 63, 1379-1389 (1968).

23. Mayo, L. R. \& March, R. S. Air temperature and precipitation at Wolverine Glacier, Alaska; Glacier growth in a warmer, wetter climate. Ann. Glaciol 14, 191-194 (1990).

24. Kelsey, E. P., Wake, C. P., Yalcin, K. \& Kreutz, K. Eclipse Ice Core Accumulation and Stable Isotope Variability as an Indicator of North Pacific Climate. Journal of Climate 25, 6426-6440, https://doi.org/10.1175/jcli-d-11-00389.1 (2012).

25. Shi, X. M. \& Durran, D. R. The Response of Orographic Precipitation over Idealized Midlatitude Mountains Due to Global Increases in CO2. Journal of Climate 27, 3938-3956, https://doi.org/10.1175/jcli-d-13-00460.1 (2014).

26. Mock, C. J., Bartlein, P. J. \& Anderson, P. M. Atmospheric circulation patterns and spatial climatic variations in Beringia. Int. J. Climatol. 18, 1085-1104, https://doi.org/10.1002/(sici)1097-0088(199808)18:10<1085:aid-joc305>3.0.co;2-k (1998).

27. Compo, G. P. et al. The twentieth century reanalysis project. Q. J. R. Meteorol. Soc. 137, 1-28 (2011).

28. Trenberth, K. E. \& Hurrell, J. W. Decadal Atmosphere-Ocean Variations in the Pacific. Clim. Dyn. 9, 303-319, https://doi. org/10.1007/bf00204745 (1994).

29. Hurrell, James \& National Center for Atmospheric Research Staff (Eds). The Climate Data Guide: North Pacific (NP) Index by Trenberth and Hurrell; monthly and winter. Retrieved from https://climatedataguide.ucar.edu/climate-data/north-pacific-npindex-trenberth-and-hurrell-monthly-and-winter. Last modified 27 Oct 2017.

30. Rodionov, S. N., Bond, N. A. \& Overland, J. E. The Aleutian Low, storm tracks, and winter climate variability in the Bering Sea. Deep Sea Research Part II: Topical Studies in Oceanography 54, 2560-2577 (2007).

31. Rodionov, S. N., Overland, J. E. \& Bond, N. A. Spatial and temporal variability of the Aleutian climate. Fish Oceanogr. 14, 3-21, https://doi.org/10.1111/j.1365-2419.2005.00363.x (2005).

32. Sato, T. et al. Accumulation reconstruction and water isotope analysis for 1735-1997 of an ice core from the Ushkovsky volcano, Kamchatka, and their relationships to North Pacific climate records. Climate of the Past Discussions 9, 29, https://doi.org/10.5194/ cpd-9-2153-2013 (2013).

33. Thompson, L. G. et al. A high-resolution millennial record of the South Asian monsoon from Himalayan ice cores. Science 289, 1916-1919(2000).

34. Henderson, K. et al. Temporal variations of accumulation and temperature during the past two centuries from Belukha ice core, Siberian Altai. Journal of Geophysical Research: Atmospheres 111 (2006).

35. Osterberg, E. C. et al. Mount Logan ice core record of tropical and solar influences on Aleutian Low variability: 500-1998 AD. Journal of Geophysical Research: Atmospheres 119, 11,189-111,204 (2014).

36. Osterberg, E. C. et al. 1200-Year Composite Ice Core Record of Aleutian Low Intensification. Geophys. Res. Lett. (2017).

37. Fisher, D. A. et al. The Mt Logan Holocene-late Wisconsinan isotope record: Tropical Pacific-Yukon connections. Holocene 18, 667-677, https://doi.org/10.1177/0959683608092236 (2008). 
38. Rupper, S., Steig, E. J. \& Roe, G. The relationship between snow accumulation at Mt. Logan, Yukon, Canada, and climate variability in the North Pacific. Journal of Climate 17, 4724-4739, https://doi.org/10.1175/jcli-3202.1 (2004).

39. Anderson, L., Abbott, M. B., Finney, B. P. \& Burns, S. J. Late Holocene moisture balance variability in the southwest Yukon territory, Canada. Quat. Sci. Rev. 26, 130-141, https://doi.org/10.1016/j.quascirev.2006.04.011 (2007).

40. Scheff, J. \& Frierson, D. Twenty-first-century multimodel subtropical precipitation declines are mostly midlatitude shifts. Journal of Climate 25, 4330-4347 (2012).

41. Ljungqvist, F. C. et al. Northern Hemisphere hydroclimate variability over the past twelve centuries. Nature 532, 94-98 (2016).

42. Deser, C., Phillips, A. S. \& Hurrell, J. W. Pacific interdecadal climate variability: Linkages between the tropics and the North Pacific during boreal winter since 1900. Journal of Climate 17, 3109-3124 (2004).

43. Alexander, M. A. et al. The atmospheric bridge: The influence of ENSO teleconnections on air-sea interaction over the global oceans. Journal of Climate 15, 2205-2231 (2002).

44. Abram, N. J. et al. Early onset of industrial-era warming across the oceans and continents. Nature 536, 411-418 (2016).

45. Tierney, J. E. et al. Tropical sea surface temperatures for the past four centuries reconstructed from coral archives. Paleoceanography 30, 226-252 (2015)

46. Diaz, H. F., Wahl, E. R., Zorita, E., Giambelluca, T. W. \& Eischeid, J. K. A Five-Century Reconstruction of Hawaiian Islands Winter Rainfall. Journal of Climate (2016).

47. Pepin, N. C. \& Seidel, D. J. A global comparison of surface and free-air temperatures at high elevations. Journal of Geophysical Research: Atmospheres 110 (2005).

48. Giorgetta, M. A. et al. The atmospheric general circulation model ECHAM6-model description (2013).

49. Dufresne, J. L. et al. Climate change projections using the IPSL-CM5 Earth System Model: from CMIP3 to CMIP5. Clim. Dyn. 40, 2123-2165, https://doi.org/10.1007/s00382-012-1636-1 (2013)

50. Collins, M. et al. The impact of global warming on the tropical Pacific Ocean and El Niño. Nat. Geosci. 3, 391-397 (2010).

51. Xie, S.-P. et al. Global warming pattern formation: sea surface temperature and rainfall*. Journal of Climate 23, 966-986 (2010).

52. Liu, Z., Vavrus, S., He, F., Wen, N. \& Zhong, Y. Rethinking Tropical Ocean Response to Global Warming: The Enhanced Equatorial Warming*. Journal of Climate 18, 4684-4700 (2005).

53. Yalcin, K., Wake, C. P., Kreutz, K. J., Germani, M. S. \& Whitlow, S. I. Ice core paleovolcanic records from the St. Elias Mountains, Yukon, Canada. J. Geophys. Res.-Atmos. 112, 21, https://doi.org/10.1029/2006jd007497 (2007).

54. Osterberg, E. C., Handley, M. J., Sneed, S. B., Mayewski, P. A. \& Kreutz, K. J. Continuous ice core melter system with discrete sampling for major ion, trace element, and stable isotope analyses. Environ. Sci. Technol. 40, 3355-3361, https://doi.org/10.1021/ es052536w (2006).

55. Yasunari, T. J. et al. Intra-annual variations in atmospheric dust and tritium in the North Pacific region detected from an ice core from Mount Wrangell, Alaska. J. Geophys. Res.-Atmos. 112, 16, https://doi.org/10.1029/2006jd008121 (2007).

56. Wake, C. P., Yalcin, K. \& Gundestrup, N. S. In Annals of Glaciology, Vol 35 Vol. 35 Annals of Glaciology (ed E W. Wolff) 416-422 (Int Glaciological Soc, 2002).

57. Yalcin, K. \& Wake, C. P. Anthropogenic signals recorded in an ice core from Eclipse Icefield, Yukon Territory, Canada. Geophys. Res. Lett. 28, 4487-4490, https://doi.org/10.1029/2001gl013037 (2001).

58. Sigl, M. et al. A new bipolar ice core record of volcanism from WAIS Divide and NEEM and implications for climate forcing of the last 2000 years. J. Geophys. Res.-Atmos. 118, 1151-1169, https://doi.org/10.1029/2012jd018603 (2013).

59. Venzke, E. E. In Global Volcanism Program (Smithsonian Institution, 2013).

60. Hannig, J. \& Marron, J. S. Advanced distribution theory for SiZer. Journal of the American Statistical Association 101, 484-499 (2006).

61. Chaudhuri, P. \& Marron, J. S. SiZer for exploration of structures in curves. Journal of the American Statistical Association 94, 807-823 (1999).

62. Watanabe, S. et al. MIROC-ESM 2010: model description and basic results of CMIP5-20c3m experiments. Geosci. Model Dev. 4, 845-872, https://doi.org/10.5194/gmd-4-845-2011 (2011).

63. Collins, M., Tett, S. F. B. \& Cooper, C. The internal climate variability of HadCM3, a version of the Hadley Centre coupled model without flux adjustments. Clim. Dyn. 17, 61-81, https://doi.org/10.1007/s003820000094 (2001).

64. Zhou, T. J., Li, B., Man, W. M., Zhang, L. X. \& Zhang, J. A comparison of the Medieval Warm Period, Little Ice Age and 20th century warming simulated by the FGOALS climate system model. Chinese Science Bulletin 56, 3028-3041, https://doi.org/10.1007/s11434011-4641-6 (2011)

65. Schmidt, G. A. et al. Present-day atmospheric simulations using GISS ModelE: Comparison to in situ, satellite, and reanalysis data. Journal of Climate 19, 153-192 (2006).

66. Yukimoto, S. et al. A new global climate model of the Meteorological Research Institute: MRI-CGCM3-model description and basic performance. Journal of the Meteorological Society of Japan. Ser. II 90, 23-64 (2012).

\section{Acknowledgements}

This research is supported by the NSF Paleoclimate Program (P2C2), Grant numbers AGS-1204035 (E.O.), AGS1203838 (K.K., S.B.), and AGS-1203863 (C.W.). Denali National Park, Polar Field Services and Talkeetna Air Taxi provided air support and field assistance. Thanks to Mike Waszkiewicz for ice core drilling, to Brad Markle, Dave Silverstone, Tim Godaire and Elizabeth Burakowski for field assistance, to Roger Hooke for scientific input, and to more than 25 students for their support in the field and the lab. Ice cores were prepared at the National Ice Core Laboratory in Denver, CO for continuous melting at Dartmouth. Figures throughout the paper were generated using Climate Reanalyzer (http://cci-reanalyzer.org), Climate Change Institute, University of Maine, USA. We thank two reviewers for their helpful comments. Data from this study are available at https://www.ncdc.noaa. gov/paleo/study/21970.

\section{Author Contributions}

E.O., K.K., C.W., and S.B. wrote the initial proposal for this study. D.W., S.C., E.O., K.K. and C.W. collected the ice core. D.W. and D.F. melted the ice core. D.F., D.I., C.W. and M.H. analyzed the samples. D.W., S.C., S.R., and B.H. conducted the flow modeling. D.W., E.O. and D.F. performed the layer counting and developed the depth age scale. D.W. and E.O. performed the climate analysis. D.W., E.O. and K.K. wrote the paper. All authors discussed the results and reviewed the manuscript.

Additional Information

Supplementary information accompanies this paper at https://doi.org/10.1038/s41598-017-18022-5.

Competing Interests: The authors declare that they have no competing interests. 
Publisher's note: Springer Nature remains neutral with regard to jurisdictional claims in published maps and institutional affiliations.

(c) (i) Open Access This article is licensed under a Creative Commons Attribution 4.0 International License, which permits use, sharing, adaptation, distribution and reproduction in any medium or format, as long as you give appropriate credit to the original author(s) and the source, provide a link to the Creative Commons license, and indicate if changes were made. The images or other third party material in this article are included in the article's Creative Commons license, unless indicated otherwise in a credit line to the material. If material is not included in the article's Creative Commons license and your intended use is not permitted by statutory regulation or exceeds the permitted use, you will need to obtain permission directly from the copyright holder. To view a copy of this license, visit http://creativecommons.org/licenses/by/4.0/.

(c) The Author(s) 2017 